\title{
FRANSCH INDO-CHINA.
}

\section{Co chinchina.}

Wij waren in Siam, in Bangkok, mijn Javaan en ik, en moesten naar Fransch Indo-China, zooals de Franschen, teekenend, Achter-Indië noemen. In den drogen tijd kan de reis over land geschieden, in een tiental clagen tot Pnom-Penh, Cambodja, op olifanten of met wagens. ') Thans, in September, viel aan de landreis niet te denken; daarvoor waren de te doortrekken streken te zeer overstroomd. De eenige geriefelijke zeeverbinding loopt over Singapoer; waarheen van Bangkok alleen de Noord-Duitsche Lloyd een geregelden dienst onderhoudt, terwijl van daar geen andere vaste booten loopen naar Fransch Indo-China dan die der Messageries Maritimes en der Chargeurs Réunis. Wil de reiziger dezen grooten omweg en deze overscheping niet, dan is hij gedwongen gebruik te maken van een oud klein stoomscheepje, de Donaï, het eenige dat van Bangkok raart op de Fransche kolonie, namelijk op Saigon.

Geheeten naar een binnenrivier, aan welke Saïgon is gelegen en die zich bij die stad in de Saïgon-rivier uitstort, behoort het bootje aan de te Parijs gevestigde maatschappij Messageries Fluviales. Deze onderhoudt ook een geregel-

1) Van deze overland-reis heeft onze landgenoot Mr. J. A. N. Patijn een tiental jaren geleden ondervinding opgedaan en die in het Tijdschrift van het Kon. Ned. Aardrijksk. Genootsch. deel XX bekend gemaakt. 
den dienst op de hoofdrivieren van Cochinchina en het daarachter gelegene Cambodja. Voor de veertiendaagsche vaart tusschen Bangkok en Saïgon moet haar de Fransche regeering jaarlijks 150.000 franken toeslag betalen. Toch heb ik nergens in de wereld een zoo gebrekkig maalschip ${ }^{1}$ ) ontmoet. De verlichting beperkt er zich in de kajuit tot een paar olielampen en ontbreekt volkomen op het dek. Daar de op Fransche reizigersbooten nooit ontbrekende administrateur, wiens taak bij. andere rolken op kleine schepen door gezagvoerder of stuurlieden wordt verricht, uit zijn karige bezoldiging alles moet rergoeden wat gebroken of vermist wordt, heeft hij de ballons voor de kaars, die de hut moet verlichten, zorgvuldig opgeborgen en waait de vlam telkens uit. Kan men aan dek na zonsondergang geen hand voor oogen zien, overdag verdrijft de hitte van daar, omdat geen houten of dubbele zonnetent beschutting biedt doch slechts een enkel zeil. De badkamer dient tevens tot berging van groenten en is dus onbruikbaar. Alles is even vuil en met niets kan men vrede hebben dan, gelijk gewoonlijk bij Franschen, met het voedsel. Met deze maatschappij legt Frankrijk geen eer in.

Drie dagen na ons vertrek van Bangkok houden wij even stil voor Poeloe Condor om er de post af te geven. Dit eilandje met Maleischen naam, welken reeds de oudHollandsche scheepsjournalen vermelden, dient de Fransche regeering als strafkolonie voor inlandsche misdadigers. Een half etmaal later ligt Kaap St.-Jacques voor ons, een versterkte berg die den ingang beschermt der Rivier van Saïgon. Als wij deze opvaren, blijkt zij een zeer breede, machtige stroom te zijn. Aan de geheel vlakke oevers beginnen weldra de rijstvelden zich te vertoonen, de rijkdom van Cochinchina. Woningen ontwaren wij nauwelijks. De rivier kronkelt zich geweldig door het alluviale, natte, uiterst vruchtbare land, totdat na vijf uur opstoomens in de verte twee torens opdoemen, die der kathedraal van Saïgon. Rechts verschijnen ellendige stroohutten van inlanders, dan een aantal boeien om aan te meren, tal van handelsvaartuigen, ook inlandsche zeilschepen voor rijstver-

1) Waarom niet het Hollandsche woord voor mail gebruikt! 
voer, en vier Fransche oorlogsstoomers. Ten slotte vertoont zich een groot gebouw, pas opgericht roor huisvesting der marine, en dan ankeren wij. Voor ons, links, ligt Saïgon.

Ofschoon nog geen halve eeuw in het bezit der Franschen, is Saïgon de eerste plaats waar deze blijvend hun macht in het Verre Oosten gevestigd hebben, het uitgangspunt van hun Oost-Aziatisch rijk.

Ook hier heeft de zending den weg bereid. Toen namelijk in 1770 een opstand in het koninkrijk Annam, dat de geheele tegenwoordige kolonie behalve Cambodja en Lans besloeg, het vorstelijke geslacht had verdelgd, vluchtte de cenig overgeblevene daarvan bij een Franschen roomschen zendeling, Pigneau de Béhaine. Frankrijk betwistte in die dagen in Voor-Indië de toekomstige oppermacht aan Engeland en greep de thans in Indo-China aangeboden gelegenheid aan. Het kwam met den rorstenzoon in 1786 overeen, hem met troepen uit Voor-Indië op den troon te helpen tegen afstand van het schiereiland Tourane en val het zooeven genoemde Poeloe Condor benevens verleening van handels- en zendingsvrijheid. De onderneming gelukte, doch wegens de inwendige beroeringen in Frankrijk maakte dit geen gebruik van zijn verkregen aanspra. ken. Na de Restauratie nam het den gevallen draad weer $o p$ en begon onderhandelingen, die echter afstuitten op volkomen onwil van Annam's koning om betrekkingen met Frankrijk aan te knoopen. Aandrang werd beantwoord met ter doodbrenging van zendelingen. Toen kwam in 1847 een Fransch eskader voor Tourane, de havenplaats van de hoofdstad Hué, en vernietigde een aantal Annamitische schepen. De in hetzelfde jaar opgetreden keizer Tu-Duc, die tot in onze dagen heeft geregeerd, wreekte zich door een moord op geestelijken en inlandsche christenen. Daar onder de eersten zich ook twee Spanjaarden hadden beronden, werkte een troepenmacht uit Manilla met Frankrijk mede om Tourane in 1858 in bezit te nemen en in 1859 Saigon. Dit was de hoofdplaats van Neder-Cochinchina, dat vroeger aan het koninkrijk Cambodja had behoord en tegenwoordig bloot Cochinchina wordt geheeten, gelijk het toenmalige Opper-Cochinchina thans Annam wordt genoemd.

Econ. 1911. 
Terwijl Tourane voorloopig weder werd verlaten bleet Saïgon sedert in Fransche handen.

Dadelijk streefde Frankrijk naar uitbreiding van deze nieuwe kolonie. Toen in 1862 de vrede met Tu-Duc werd gesloten, ontwrong het dezen behalve de verbintenis tht betaling van 17 millioen franken aan oorlogsschatting roor zichzelf en 3 millioen voor Spanje, het eilandje Condor en het Saïgon omgerende gebied '), waaronder de stad Mytho, die belangrijk was wegens haar ligging dicht bij zee aan de hartader des lands, aan de Mekong. Daarop, in 1863, wendde Frankrijk zich tot den koning Norodom ran Cambodja, die eveneens tot in onze dagen heeft geregeerd. Zijn voorganger had zich, reeds in de vijftiger jaren, tot keizer Napoleon gericht om steun tegen Siam en Annam, zonder goeden uitslag. Thans overreedde Frankrijk Norodom om zich aan de cijnsplichtigheid tegenover de vorsten ran deze beide rijken en hun opperheerschappij te onttrekken en zich onder bescherming van Frankrijk te stellen, waartegen dit hem zijn troon waarborgde. Vier jaar later volgde de uitbreiding der Fransche bezitting tot de Cambodjaansche grens.

In die dagen voelde men in Frankrijk al zeer weinig voor deze kolonie en liet haar in hoofdzaak over aan de koloniale ambtenaren. Met ijver doch evenzeer met alle gebreken der onervarenheid gingen deze aan den arbeid, Fransche zeden, instellingen en inzichten overplantend, zooveel maar mogelijk bleek. De belangstelling der overheid in het moederland werd eerst gewekt, toen in de dagen van den eersten minister Jules Ferry koloniale uitbreiding het middel scheen om aan de Fransche nijverheid door een uitzonderingstarief afzet te bezorgen tot prijzen, welke den opgekomen arbeidersstand hooge loonen zouderı verschaffen en in de vrije markt niet te bedingen zouden 7ijn; een te wenschelijker: afzet, omdat het in 1880 ingetreden stelsel van bescherming de voortbrenging overprikkelde. Toen werden in oude archieven lang verwaarloosde en vergeten aanspraken te voorschijn gehaald, bijv. voor Madagascar en voor West-Afrika, werd voorts de verovering

1) Namelijk de provinciën Bien-Hoa, Gia-Dingh en Dinh-Wong. 
van Tunis voorbereid en trachtte men ook in Indo-China aanleiding tot verdere uitbreiding te vinden. Dit is gelukt. Hoe, zal in de volgende hoofdstukken blijken.

Het Fransche gebied in Indo-China, d. w. z. tusschen Hindostan en China, bestaat thans uit viji aaneengesloten stukken. Vooreerst uit Cochinchina, het zuidelijkste stuk, dat reeds onder denzelfden naam door onze eigen zeevaarders in onzen gouden tijd werd vermeld. Daar ligt de belangrijkste stad der geheele kolonie, Saïgon, en daar wordt in den rorm van rijst de rijkdom roortgebracht, die door de uitvoerrechten voorziet in de tekorten op de begrooting der andere deelen. Toch is de bevolking van Cochinchina noch groot, noch dicht, 3.000.000 inwoners op 57.000 vierkante kilom.; Java, ofschoon slechts $2 \frac{1}{2}$ maal zoo groot, heeft juist 10 maal meer inwoners. Achter Cochinchina ligt het tweede deel der kolonie, het koninkrijk Cambodja, dat, ofschoon evenzeer aan zee gelegen, economisch bijkans geheel van Cochinchina afhankelijk is, doordat zijn waterweg naar zee, de beide armen van de Mekong, door Cochinchina heen ligt. Het strekt zich orer het drievoudige oppervlak van Cochinchina uit (175.000 vierk. kilom.) en telt zelfs niet de helft der inwoners daarvan. Het derde deel, het tegenwoordige koninkrijk Annam, vormt een lange, economisch weinig belangrijke kuststrook aan de anderc zijde van Cochinchina; het heeft $5 \frac{1}{2}$ millioen inwoners op 160.000 vierk. kilom. grondgebied. Achter Annam en geheel van de zee afgesloten strekt zich het grootste doch minst bevolkte deel der kolonie uit, het zoogenaamde Laos, dat onze vaderen whet land der Louwen noemden. Meer dan dubbel zoo groot als Java herbergt het nog geen millioen menschen; het is uiterst moeielijk bereikbaar, bergachtig en economisch vooralsnog van zeer weinig beteekenis. Het noordelijkste en vijfde gebied wordt gerormd door Tonkin, na Cochinchina het kleinste $(120.000$ vierk. kilom.) doch met zijn 6 millioen zielen het rolkrijkst. ${ }^{1}$ )

Alles te zamen genomen heerscht dus Frankrijk in IndoChina over een 16.000 .000 inlanders en een gebied van

1) De laatste statistische cijfers aangaande het oppervlak en de be- 
800.000 vierkante kilometer, beide cijfers ongeveer veertig percent van de overeenkomstige in ons Oost-Indisch rijk.

Nog een klein stukje kust met bijbehoorende eilandjes bezit Frankrijk, in de buurt doch niet naast een dezer landen gelegen, nl. Kwan-Tsjeoe-Wan. Het ligt tegenover Hongkong en werd aan China ontwrongen in 1900, toen Duitschland met Kiautsjau was voorgegaan. Dat Frankrijk hicr een goede keus zou hebben gedaan, heb ik nooit ge hoord. Tegenwoordig heeft dit stukje nog niet de minste beteekenis. Staatkundig vormt het een onderdeel van Fransch Indo-China.

Sedert eenige jaren worden de gezamenlijke deelen der kolonie dnor een gouverneur-generaal geregeerd en de genoemde onderdeelen elk door een résident-supérieur, behalve Cochinchina, welks hoofd lieutenant-gouverneur heet, en Kwan-Tsjeoe-Wan, dat door een administrateur en chef wordt bestuurd. Onder deze hoofdambtenaren werken een groot aantal residenten, ongeveer gelijkstaande met controleurs in Nederlandsch-Indië. Cochinchina en Tonkin, be-

volking van Fransch Indo-China, rolgens de koloniale statistiek van 1906, zijn de volgende.

\begin{tabular}{|c|c|c|c|c|c|}
\hline \multirow[b]{2}{*}{ Gewesten. } & \multirow{2}{*}{$\begin{array}{c}\text { Opper- } \\
\text { vlakte in } \\
\text { vierkante } \\
\text { kilom. }\end{array}$} & \multicolumn{3}{|c|}{ BEVOLKING. } & \multirow[b]{2}{*}{ Totaal. } \\
\hline & & $\begin{array}{c}\text { Euro- } \\
\text { peanen. a) }\end{array}$ & Inlanders. & $\mid \begin{array}{c}\text { Half- } \\
\text { bloeden. }\end{array}$ & \\
\hline & & & 90 & & \\
\hline Cambodja. & & 720 & 845 & 10.969 & 534 \\
\hline Annam: & 90 & 1.644 & 31 & 4.906 & 681 \\
\hline Tonkin & 50 & 7.120 & 5.8 & 451 & 5.896 .510 \\
\hline Laos. & 290 & 191 & 43 & 193 & 6633.727 \\
\hline Kouang-'Tchcou-Wan. & 1.000 & 55 & 177.031 & 11 & 177.097 \\
\hline ndo-China & 808 & 90 & 2.579 & 18.594 & \\
\hline
\end{tabular}

a) De Europeanen van de land- en zeemacht, niet begrepen onder de bovenstaande eijfers, bedragen in:

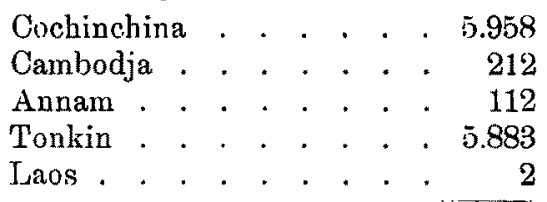

Totaal . . 12.167 mannen. 
hoord hebbende aan de Annamitische kroon, staan niet meer onder een inlandsch vorst; doch Cambodja en Annam hebben hun koningen behouden, en geheel Laos heeft tegenwoordig den koning te Luang-Prabang tot hoofd.

Gaan wij thans te Saigon aan den wal.

Een ras vertoont zich, opvallend verschillend in lichaamsvolm en kleeding van eenig volk buiten Fransch Achter-Indië. $\Lambda$ i maakt Cochinchina geen deel uit van het eigenlijke Annam, toch verschillen zijn bewoners niet van de bevolking van dat rijk en heeten zij Annamieten; inderdaad vormen de bewoners van Cochinchina, Annam en Tonkin éen ras, met ongeveer eenzelfde taal, eenzelfde Chineesch schrift en eenzelfden godsdienst, een uiterst verbasterd en vermengd Boedisme, waarover in de beide volgende hoofdstukken zal gesproken worden. Hun tengere, lenige gestalten steken uit boven die van den gemiddelden Siamees en Javaan, zonder echter de breedte en lengte der Chineezen te bereiken. Hun gelaatstrekken schijnen te wijzen op een vermenging van Maleiers en Chineezen, doch komen het meest de Maleische nabij. Slechts even stekin de jukbeenderen uit, de oogvorm nadert meer den onze dan den gespletene van het Mongoolsche ras, de huidskleur is heel lichtbruin, bijna blank. Hun uitdrukking spreekt van beschaving, verfijning zelfs en van een zachten aard. Veelvuldig ziet men rrouwen met aantrekkelijk uiterlijk, dat echter raak ontsierd wordt door zwart gelakte tanden als op Java.

In tegensteliing met de kleeding der andere volken van Oust-Azië beperkt zich die der Annamieten grootendeels tot wit en zwart. Boven hun wijde, slappe, tot den grond nederhangende katoenen broeken dragen zij een zwart overkleed, dat, behalve bij de handwerkslieden, over de knieën neerhangt. Om de slapen hebben zij zich als een lauwerkrans een opgerolde zwarten of witten doek geslagen, die de in een korten wrong saamgerolde, bij beide seksen lang gehouden haren laat zien. De bloote voeten steken in sandalen, die van voren onnoodig lang zijn en sterk opwippen. Van de vrouwen verschilt de kleeding nauwelijks van die der mannen.

Een aantal inlanders dragen krijgskleedij. De Fran- 
sche regeering vordert namelijk van elk dorp eenige soldaten, evenals de Engelsche van de inlandsche staten in Voor-Indië; ook de zoogenaamde Gefedereerde Maleische Staten op het schiereiland Malakka hebben zich bij verdrag moeten verplichten, desverlangd krijgslieden aan den Britschen overheerscher te leveren. Het zijn voorbeelden die voor Nederlandsch-Indië.misschien de aandacht verdienen. Frankrijk heeft deze lieden ten deele wonderlijk uitgedost, door hun een ronde schijf bij wijze van hoed op het hoofd te plaatsen, die van voren uitsteekt, slechts de helft van het hoofd bedekt en door een kinband moet worden vastgehouden. Qverigens is hun kleedij praktisch, een kiel en korte broek van kaki katoen, donkerblauwe wollen reepen, zoogen. poeti's, om de kuiten gewonden; de voeten blijven bloot.

Ook Chineezen vertoonen zich, gelijk overal in het Verre Oosten.

Het uiterlijk der stad echter verplaatst ons geheel naar Europa, naar de Fransche provincie. De kade is bezet met regeeringsgebouwen en kantoren, enkele verdiepingen hoog en in uiterlijk niet verschillend van Europeesche. Loodrecht daarop loopt de voornaamste straat, de rue Catinat, die aan beide zijden achter boomen een rij van electrisch en schitterend verlichte winkels vertoont. Dan bereikt men een groot plein, aan één kant afgesloten door een waarlijk zeer [raaien en grooten schouwburg en aan twee andere zijden door ruime koffiehuizen, waarvoor en waarin thans een drom menschen hun apéritif zitten te gebruiken, een eenig schouwspel voor Oost-Azië. Iets verderop in dezelfde straat ligt het beste hotel, het Continental, eenige verdiepingen hoog, niet.kwaad doch duur; men moet er 15 gulden per dag voor kost en inwoning betalen. De straat loopt uit op een plein met in zijn midden een nieuwerwetsche romaansche kathedraal, een ruim, weinig versierd, eenvoudig gebouw. Links daarvan verrijst een monumentaal postkantoor, dat een sieraad zou zijn voor een Fransche provinciestad. Een gezellige drukte heerscht in deze buurt tot laat in den avond. En nog lang nadat ik mij ter ruste begeven heb, dringt in mijn vertrek het gegalm door van café-chantant- 
zangeressen en het geschreeuw uit de volle koffiehuizen om "pousse-puusses», zooals men hier de riksja's noemt, alsof zij geduwd inplaats van getrokken worden.

Den volgenden dag blijkt ons Saïgon inderdaad een fraaie stad te zijn. Op de winkelbuurt volgen een aantal breede lanen, zwaar belommerd door hoog geboomte, waarachter te midden van tuinen verscheidene weidsche regeeringsgebouwen, alle eenige rerdiepingen rijk, gelegen zijn, het stadhuis, het paleis van den gouverneur-generaal, het pa. leis van justitie, dat van den luitenant-gouverneur van Cochinchina enz. Men heeft de stad gevuld met standbeelden, waarmee men in Frankrijk blijkbaar geen weg wist. Daar redevoert bijv. Gambetta, trots het heete klimaat gehuld in een pels; aan zijn voet nemen twee soldaten een rerdedigende houding aan, "la défense nationale». Wat doet clit beeld hier? Daar staan ook verscheidene aanvoerders ran leger en vloot die de kolonie hebben veroverd, een paar met veel te groote hoofden; men ziet het, de Fransche beeldhouwers hebben bestellingen noodig. Ook den Tour du Buis bootst men na; tegen zonsondergang trekt al wat blank is en over een rijtuig beschikt door den fraaien dieren- en plantentuin naar buiten, en daar gaat men in lange aaneengesloten rijen elkander voorbij, groetend, kijkend en aanmerkingen makend.

Ofschoon de huurprijzen der Europeesche woningen veel hooger zijn dan op Java en bijvoorbeeld voor huisjes van vier vertrekjes ongeveer honderd gulden per maand moet betaald worden, vallen de woonhuizen tegen. Zij halen niet bij die op Java. Slechts kleine vertrekken bevatten $z i j$, over twee verdiepingen verdeeld, hebben alleen aan één kant een smal veranda'tje en staan op bekrompen, slecht verzorgde erven. Deze gebrekkige toestand moet een uitvloeisel zijn van de omstandigheid, dat de Fransche ambtenaren, die verreweg de meerderheid uitmaken der blanke bevolking, om de drie jaren recht hebben op verlof naar Europa, een tijdperk dat gemeenlijk, zoogenaamd om gezondheidsredenen, tot twee jaar wordt ingekort. Daardoor vindt men het niet de moeite waard aan de woning: veel zorg te besteden en is men niet kieskeurig.

Belangrijke inlandsche gebouwen bevat Saïgon niet; zij 
is een bijkans uitsluitend Fransche stad. De Annamitische schouwburg bijv. staat in een achterbuurt, is slecht onderhouden, $r$ uil en leelijk. De voorstellingen, verschillen voor het oog niet van die in China en duren als daar soms vele avonden achtereen.

Het Fransche tooneel geniet grooten steun uit de koloniale schatkist met het doel den Franschen het leven minder van dat in het moederland te doen verschillen en hen in de kolonie te houden. Driemillioen francs heeft de regeering aan het gebouw besteed en buitendien zorgt zij dat van October tot April zoowel een opera- als een tooneel-gezelschap uit Frankrijk verscheiden malen per week uitvoeringen geven. De plaatsen zijn er niet duur en gewoonlijk moet de regeering jaarlijks 300.000 franken bijpassen. Desniettegenstaande was een door mij bijgewoonde voorstelling door een troep uit Tonkin zoo slecht, dat ik, ofschoon men in het Verre Oosten op tooneelgebied zeker niet verwend wordt, halverwege moest wegloopen.

Den geringen lust en drang in Frankrijk tot het verlaten van het moederland in aanmerking genomen, telt Saigon een groot aantal Fransche inwoners, zesduizend. $\mathrm{Zij}$ leven in Indo-China niet naar het Britsch-koloniale doch naar het voorbeeld der Hollanders in Indië, gaan 's middags ter ruste en kleeden zich als deze, echter volgens den militairen snit, nl. met nauw sluitende buizen en aan de knieën ontzaglijk wijde broeken. Ook zij doen niet veel aan lichaamsoefening, al zag ik hier een wedkamp in voetbal tusschen soldaten en burgers. Andere Europeanen wonen er nog geen tweehonderd. Voorts twaalfduizend Chineezen. De rest der 50.000 inwoners wordt gevormd door Annamieten.

Saïgon ondergaat de nadeelige gevolgen van de verplaatsing in 1903 der centrale regeering naar Hanoï. Deze verplaatsing had ten duel het verarmde Tonkin aan meer inkomsten te helpen en den gouverneur-generaal in staat te stellen aan dit, het laatst veroverde en nog steeds niet tot rust gekomen gebied zijn bijzondere zorgen te wijden. Men hoopte ook op uitbreiding der kolonie ten koste van China en roor clat doel was Hanoï beter gelegen. Thans 
echter is die hoop verdwenen, Hanoï ligt in een uithoek, niet aan zee, terwijl de toegang tot Saïgon versterkt is en de stad en haar omgeving daardoor de meeste troeper hebben. Buitendien ligt Saïgon te midden van het rijkste gewest van de kolonie, dat voor de schatkist het grootste belang heeft, en bezit het talrijker en betere verbindingen over zee clan het weinig uitroerende en door zeeschepen slecht bezochte Haïphong, de voorhaven van Hanoï. Al deze redenen te zamen geven uitzicht, dat het paleis van den gouverneur-generaal te Saïgon eerlang weder door dezen zal worden bewoond.

Juist in deze dagen ${ }^{1}$ ) kwam er de pas benoemde gouverneur-generaal op zijn doorreis voor enkele dagen zijn intrek nemen. Door zijn benoeming heeft de Fransche regeering te recht gebroken met de gewoonte, aan het hoofd der ko'onie politici le plaatsen, mannen die, hoe bekwaam ook, koloniale ondervinding misten. In tegenstelling met Britsch-Indië,' waar de gouverneur-generaal niet alleen in titel doch inderdaad onderkoning is, wiens werk zaamheid niet verder gaat dan die van een constitutioneel vorst, is in Fransch Indo-China evenals in Nederlandsch-Indië de gouverneur-generaal de regeerder. Met den besten wil en de hoogste bekwaamheid kan hij zonder koloniale kennis zijn taak niet in allen deele bevredigend vervullen. De heer Klobukowski, de nieuw benoemde, is hier vroeger burgerlijk ambtemaar geweest, consul-generaal in Japan en Voor-Indië en gezant in Siam, een man van de daad, sterk en beslist.

Eenroudig is zijn omgeving, in overeenstemming met republikeinsche zeden; ran een klein hof zooals te Buitenzorg, daar zeker niet overdreven, is hier nauwelijks sprake.

Dat hij niet meegaat met de hooggestemde en onrechtmatige rerwachtingen, die men in Frankrijk met verbazing hoort, omtrent de gevoelens der inlanders ten opzichte der Franschen, bleek uit zijn opmerking aan den disch: «Men kan van de inlanders niet in ernst verwachten, dat zij cons zouden liefhebben; wij hebben ons door geweld aan

1) September 1908. 
"hen opgedrongen. Maar wij moeten hun de overtuiging geven, dat zij onder ons beter af zijn dan onder anderen of ten minste even goed.» Ziedaar een gezond beginsel.

Ook voor die overtuiging bestaat thans niet in alle opzichten aanleiding. Cochinchina, Frankrijk's lagere school als Aziatische mogendheid, zucht onder al te zeer Fransche bestuursinstellingen, te veelvuldige vervanging der inlandsche ambtenaren door Franschen; en kennisneming der opvolgende koloniale verslagen leert, reeds voordat men de kolonie heeft doorreisd, dat de Franschen in hun Indo-China, behalve op uiterst bescheiden schaal in Tonkin, niet zooals de Nederlanders in hun koloniën nieuwe bestaansmiddelen hebhen gebracht en dat zij integendeel ten slotte allen leven op den arbeid der bevolking. Dit zal uit de volgende bladzijden blijken en werd ook, na eenige aarzeling, aan denzelfden maaltijd toegegeven.

In tegenstelling met de Nederlanders in hun Aziatisch rijk, wijden zich de Fransche particulieren bijna uitsluitend aan het winkelbedrijf. Den groothandel hebben de vreemdelingen zoo goed als geheel vermeesterd, in de eerste plaats Chineezen, dan Duitschers en ook een aanzienlijk Hollandsch-Zwitsersch handelshuis.

Dit laatste, de firma Diethelm \& Co., is een spruit van het bekende Singapoersche kantoor Hooglandt \& Co., dat rok in Bangkok is gevestigd en te Zurich zijn hoofdzetel heeft, daar de tegenwoordige hoofdeigenaar een Zwitser is. Aan het hoofd van den Saïgon-tak staat een sympathieke junge Amsterdammer, de heer Röst, die als consul roor de geheele kolonie ons land vertegenwoordigt. Beroepsconsuls telt deze heelemaal niet, omdat Frankrijk het land zooveel mogelijk voor vreemde handel en ondernemingsgeest gesloten houdt. Nog een tweede handelslichaam, de Banque de Cochinchine, stat te Saïgon onder de gedeeltelijke leiding van een Amsterdammer, evenzeer een kweekeling ran de handelsschool aldaar.

Ook bier hebben de Voor-Indische geldwisselaars en kleine bankiers, de zoogenaamde chittie's, zich genesteld, kenbaar aan hun naakte bovenlijf, kaalgeschoren hoofd en de kostbare gouden halsketting met prachtige juweelen 
sluiting. $\mathrm{Zij}$ hebben zich hier een tempeltje gebouwd, dat niets bevat dan cen Visjnoe; het beeld schuilt geheimzinnig weg op den achtergrond van een half duister, ontoegankelijk kapelletje en wordt slechts even door een paar lampjes verlicht.

Ofschoon de Franschen al hun best doen om hun taal in de kolonie te verspreiden en hier slechts bij uitzondeling een andere machtig zijn, bedient zich de groothandelaar ter plaatste in hoofdzaak van het Maleisch, omdat dit door de Chineezen het best verstaan wordt. De koopman, die deze taal niet machtig is, behoeft een comprador, Chineeschen tusschenman die deel ran zijn vast personeel uitmaakt.

Terwille van den handel met de omringende zilverlanden, voornamelijk met het oog op China, buur van Tonkin, heeft de regeering weerstand gebuden aan de gehechtheid der Franschen aan eigen instellingen, in zooverre als zij niet het Fransche muntstelsel heeft ingevoerd maar den dollar en zilveren standaard heeft behouden. Buiten Nederlandsch-Indië is de dollar in het geheele Verre Oosten de standaardmunt. Naar gelang van plaats en in de zilverlanden ook naar gelang van tijd verschilt zijn waarde, doch beweegt zich tusschen fl. 1 en fl. 1.40 Ned. courant; gemiddeld kan men den Aziatischen dollar evenals den yer en den roebel rekenen voor een halven Amerikaanschen. Ook in Indo-China is de dollar, door de Franschen piaster genoemd, ongeveer $1 / 10$ van een pond sterling waard. Hij draagt er het stempel der Republiek. Evenzeer de koperen cent; de keerzijde vertoont inlandsche letters̄ en het stuk is op Chineesche wijze doorboord. Van koning Norodom van Cambodja loopt eveneens kopergeld om, gestempeld met zijn beeltenis en wapen, echter met de vermelding dix centimes", ofschoon de Fransche munt hier geen centimes kent. De Franschen hebben namelijk in hun eersten tijd hun nationale geldlstukken hier gebruilit naast de inlandsche, Mexicaansche en Spaansche, die zij hier in omloop vonden; thans zijn die grootendeels verdwenen. Bankbiljetten geeft de Banque de l'Indo-Chine uit en zij heeft die, weder ter wille van den handel, naast den Franschen tekst met een Engelschen bedrukt. Sedert ook in 
$\Lambda z i e ̈$ maatregelen zijn genomen om een eind te maken aan de heftige schommelingen van den zilverkoers, die het verkeer op losse schroeven zetten en soms een aantal percenten in één week bedragen, heeft de Fransche regeering, wier begrooting daardoor evenzeer onzeker wordt, achtereenvolgens verschillende staatscommissies benoemd om het muntstelsel der kolonie aan een onderzoek te onderwerpen. Tot wijziging is het nog niet gekomen en zulks met het oog op het verkeer met China.

Niet te Saigon worden de grootste zaken gedaan, maar in de stad, die de Chineezen zich meer dan een eeuw geleden op vijf kilometers afstand van Saïgon hebben gesticht, Cholon geheeten; ik hoor dezen naam gewoonlijk uitspreken als Cheulèn. $\mathrm{Zij}$ telt thans reeds $2 \frac{1}{2}$ maal meer inwoners dan Saigon, waarmede zij zoowel door een kanaal als door een stoomtram verbonden is. Cheulèn blijkt een geheel Chineesche stad. Het krioelt er van menschen en zelfs het kanaal kan men er overal te voet oversteken wegens den dichten drom van zware booten en lichters, bijna uitsluitend voor het vervoer der rijst gebruikt. Van deze opeenhoping van Chineezen is een groote sterfte het gevolg, vooral onder de kinderen; duch de Fransche overheid heeft door haar gezondheidsmaatregelen in 8 jaar tijds het cijfer der kindersterfte van $66 \%$ tot $22 \%$ weten terug te brengen. Een geheele wijk bevat niets dan winkels, alle naar Chineeschen trant, boven van een balcon voorzien en op den beganen grond vensterloos. Aan de kade zetelt de Chineesche groothandel, die ook in Cochinchina de tweede hand vormt, de brug tusschen de Europeesche in- en uitvoerhuizen te Saigon eenerzijds en den winkelier en inlandsche voortbrengers anderzijds, doch die evenzeer voor eigen rekening de rijst uitvoert, het eenige voortbrengsel van beteekenis van den landbouw. Een aantal reusachtige rijstpellerijen bezitten zij hier, de Europeanen slechts een, eigendom van het grootste Europeesche huis der geheele kolonie, de Duitsche firma Speidel \& Co. Deze fabrieken doen noch in omvang noch met haar inrichting onder voor groote en nieuwerwetsche in Europa.

Ik bezoek een ervan, die eenige verdiepingen hoog is en 20 ton per dag levert. De Chineesche eigenaar is juist 
aan het rekenen op zijn telbord, bestaande uit klosjes die op een aantal stokjes heen en weer geschoven worden; in een oogwenk vermenigvuldigt en deelt hij daarmede groote getallen, veel gauwer dan wij het op papier kunnen. Het heele personeel der fabriek is Chineesch, behalve twee der drie machinisten, een Duitscher en een Engelschman, en eenige Annamitische handwerkslieden, waaronder ook vrouwen. De laatsten verdienen $\$ 0.20$ per dag, ongeveer een Hollandsch kwartje, de mannen het dubbele claarvan. Veel werkvolk is echter niet noodig, aangezien de geheele bewerking geschiedt met stoomwerktuigen, door de eigenaars uit Duitschland en Engeland ontboden. Gestookt wordt met een gedeelte van den rijstafval; de rest daarvan verkoopt men voor varkensvoeder of na verbranding voor bemesting. Vaak chartert dit huis stoombooten van of - door nnze Java-China-Japan lijn roor de ladingen die het aan Chineezen op Java heeft rerkocht. Een geregelde vaart dier lijn op Saïgon bestaat niet en zou toch, naar ik hoor, waarschijnlijk genoegzame lading aan rijst vinden. Thans wordt Saigon alleen geregeld aangedaan door de drie in den aanvang genoemde, door den staat zwaar ondersteunde Fransche lijnen. Dat de Chineezen ook de bekwaamheid en ondernemingsgeest toonen voor den groothandel over zee, daarin hier dc Europeanen zelfs verdringen en de groote nijverheid aan zich hebben getrokken, geeft te denken en voorspelt weinig goeds voor de Europeanen in het Verre Oosten, zelfs op den duur voor de voortbrenging van Europa zelf. En als hun vierhonderd millioen eens een krachtige centrale regeering zullen hebben gekregen en in krijgszaken zullen zijn geschoold, dan komen de Franschen in Indo-China het eerst aan de beurt om door hen te worden verdreven...

Is Frankrijk niet geslaagd in Cochinchina evenmin als elders in de kolonie om een andere groote teelt naast de oude nationale voortbrenging van rijst in te voeren, wel heeft het de laatste ontzaglijk doen toenemen. In de zeventiger jaren toch voerde Saigon tusschen de vijf en zes millioen picols, dus ongeveer 330.000 ton per jaar aan rijst Lit, waarvan een kwart zijn weg nam naar Java, 1) die 330.000

i) Deze eijfers zijn ontleend an een uitvoerige studie over "de 
ton hebben zich in de laatste jaren verdrie-, ja verviervoudigd. 1) Het tegenwoordige Annam kan geen rijst in belangrijke hoeveelheden uitvoeren, omdat het te bergachtig is en te arm aan rivieren; ook staat het in regenval een derde bij Cochinchina ten achter. ${ }^{2}$ ) Tonkin voert wel uit doch trots zijn veel grooter oppervlak en bevolking nog geen zesde van Cochinchina. In het geheel heeft de Fransche kolonie van 1897 tot 1.906 jaarlijks gemiddeld 845 duizend ton aan rijst uitgevoerd ${ }^{3}$ ) en in het volgende jaar bijkans dubbel zooveel. $\left.{ }^{-1}\right) \mathrm{Na}$ Siam en Birma voorziet zij thans het meest in de wereldbehoefte aan rijst en streeft Birma in den allerlaatsten tijd zelfs op zijde. ${ }^{5}$ )

De groote vooruitgang op dit gebied is in hoofdzaak aan het Fransche bestuur te danken, doordat dit zoowel de binnenlandsche onlusten heeft doen eindigen als de afpersingen der inlandsche ambtenaren zooveel mogelijk beperkt en de belastingen op een vasten roet gevestigd heeft. In den laatsten tijd zijn jaarlijks telkens een 50.000 hectaren nieuwe rijstvelden aangelegd in Cochinchina, en in Tonkin $1 / 4$ daarvan. Aan het einde van 1906 schatte men deze in eerstgenoemd gewest op 1.442 .000 hectaren ${ }^{6}$ ).

Voorziet de kolonie met Siam en Birma thans o. a. in re behoefte van Nederlandsch-Indjë en zelfs nu en dan

Franschen in Indo-China", Zaltbommel 1878, welke wij danken aan den Controleur bij het Binnenlandsch Bestuur op Java J. A. B. Wiselius als gevolg van zijn reis door Cochinchina en Cambodja.

1) De uitvoer van rijst van Cochinchina bedroeg namelijk in het tiental jaren 1897 tot 1906 gemiddeld 733.000 ton van 1000 kilo volgens de Annuaire Général de l'Indo-Chine, Hanoi 1908 blz. 161. Het volgende jaar, 1907, bedroeg de uitvoer van hetzelfde gewest zelfs 1.258 .000 ton, een. waarde van 136 millioen franes (Bulletin Economique $\mathrm{N}^{\circ}$. 73, Hanoï 1908 blz. 413). Het jaar $1909 \mathrm{zag}$ dezen nitroer weder wat dalen, tot 900.000 ton, waarvan $\frac{1}{8}$ Nederlandsch-Indië bereikte (Alg. Exportblad van 21 Mei 1910).

$\left.{ }^{2}\right)$ In Cochinchina gelijk in Cambodja en Tonkin bedraagt die $1 \frac{1}{2}$ meter per jaar en in overig Indo-China slechts 1 meter.

3) Annnaire Général 1908 blz. 161.

4) Bulletin Economique No. 73 bl. 414 .

5) Discours du Gouv. Gén. à l'ouverture de la Session ordinaire du Couseil Supérieur Nov. 1909, Saïgon Landsdrukkerij 1909 blz. 111.

) Annuaire Général 1908 blz. 162. 
rât net oude rijstland Japan, dat in de dagen der vestiging aldaar van de Nederlandsche Handel-Maatschappij nog groote hoeveelheden rijst uitvoerde, zij levert aan Frankrijk zelfs al de daar benoodigde rijst. Sedert 1898 toch $z$ ijn "van alle douanenrechten vrijgesteld de voortbreng"selen van Indo-China, die naar Frankrijk of Fransche "koloniën worden uitgevoerd".

Den uitvoer naar den vreemde daarentegen, bij verre de helangrijkste, heeft Frankrijk, evenals de Britsche overheid in Birma den geheelen uitvoer, aan een hoog recht onderworpen, 1) dat voor witte rijst naar mijn becijfering ongeveer $21 / 2 \%$ bedraagt van de waarde; voor ruw gepelde rijst, die men in het land wil houden omdat zij het volksvoedsel uitmaakt, $4 \frac{1}{4} \%$; terwijl de paddie, de rijst in den bolster, hezwaard wordt met een recht, dat bijkans $11 \%$ bedraagt, omdat de regeering de rijstpellerijen der kolonie wil beschermen. ') Buitendien moet nog een titvoerrecht betaald worden, dat de plaats van grondbelasting inneemt, overal in Indo-China behalve in Cambodja. ${ }^{3}$ ) Deze laatste bijgeroegde rechten laten zich op pl.m. $4 \%$ der waarde in de kolonie becijferen. Gezamenlijk vult de rijst met haar uitvoerrechten voor een tiende deel t) de koloniale schatkist.

Tegen uitvoerrechten pleiten in het algemeen ernstige theoretische bezwaren en Nederland heeft er op dien grond roor zijn Indiè mede gebroken. Dat zij in bepaalde gevallen echter boven andere belastingen te verkiezen zijn, daarvan geeft Engeland, dat in Nederland zeker niet van achterlijkheid op koloniaal gebied wordt beschuldigd, een sprekend voorbeeld in Malakka, nog sprekender dan in Birma, omdat het er onverdeelde instemming vindt. Ook

1) N. l. voor paddy (rijst in den bolster) frs. 0.76 ) riz cargo (ruw gepelde rijst). . 0.42$\}$ per 100 kilo. riz blanc... . . . . . " 0.32

2) Paddie wordt daardoor weinig uitgeroerd en witte rijst het meest.

3) N. l. paddy. . . doll. 0.12 $\left.\begin{array}{lll}\text { riz cargo : } & " & 0.15 \\ \text { riz blanc. : } & " & 0.19 \\ \text { brisures . : } & " & 0.09 \\ \text { farines : } & " & 0.05\end{array}\right\}$ per 100 kilo.

i) De berekeningen, die mij tot deze percentages gebrncht hebhen, zijn wat te uitvoerig om hier te worden meegedeeld. 
hier werkt het recht voortreffelijk en tot algemeene tevredenheid,

Met betrekking tot de rechten op den invoer is Frankrijk begonnen met Saïgon tot vrijhaven te verklaren, in de hoop er een ernstig mededinger van Singapoer van te maken en den handel van Indo-China erover te trekken. Daartue ontbraken echter zoowel de geschikte ligging als handelskrachten. Men heeft dus dezen maatregel ingetrokken en huldigt thans, in verband met den onder de republiek sterk gegroeiden wensch naar bescherming, de leer, dat haar offers in bloed en geld aan het moederland behooren te worden vergoed door een sterke bevoorrechting zijner nijverheid en die zijner koloniën. Vreemde lijnwaden bijv. moeten $30-40 \%$ betalen, terwijl die, op Fransch gebied voortgebracht, vrij kunnen binnenkomen. Dientengevolge voert men $o$ a. op groote schaal ongebleekte katoenen stukgoederen aan uit het Fransche stadje Pondichéry, in VoorIndië gelegen, waar zij echter door Britsche fabrikanten worden geweven, terwijl de benoodigde garens naar algemeene overtuiging uit Engelsch Voor-Indië te Pondichéry worden binnengesmokkeld. Trots deze voordeelen voorziet de Fransche nijverheid nog niet voor de helft in de be. hoefte der bevolking aan ingevoerde goederen "); "meer sdan de helft der goederen in de kolonie verbruikt komen "uit China, Duitschland en Engeland", klaagt de directeurgeneraal der douanen. ${ }^{2}$ )

Buitendien geniet de Fransche vlag, die reeds door premies op den aanbouw, door directe ondersteuning voor geregelden dienst en postvervoer, en door een uitsluitend recht op het vervoer van regeeringsreizigers en -goederen begunstigd is, nog een sterke bescherming van gelijksoortigen aard als aăn de Nederlandsche vlag ten deel viel in Insulinde ten dage van onze groote zeilvloot. Goederen, die niet met Fransche schepen komen, moeten namelijk het maximum-tarief betalen, terwijl op waren, door Fransche

1) In 1907 bracht Nederlandsch-Indië hier voor drie millioen franes, voornamelijk petroleum. Zie Bulletin Economique, Hanoï 1908 №. 73, b]z. $387 / 88$.

2) Idem, blz. 377 . 
schepen aangevoerd, het minimum-tarief wordt toegepast dat een $40 \%$ lager is.

Voorts krijgen alleen Franschen concessies, bestellingen en voorrechten.

Dit stelsel heeft de prijzen opgejaagd; het leven is duur in Fransch Indo-China. Toch geeft de inlander niet van armoede blijk, althans in de drie deelen der kolonie die ik bezocht heb, nl. Cochinchina, Cambodja en Tonkin. Hij kan de zware lasten dragen, zijn heerendienst, jaarlijks vijftien dagen in Cochinchina, zijn dessa- en militaire plichten, dank zij de overvloedige bewatering en vruchtbaarheid van sommige deelen der kolonie en de geringe dichtheid harer bevolking. ${ }^{1}$ )

Dit laatste verschil met Java vertoont het veld, zoodra men Saïgon heeft verlaten. Over goede wegen, die nogniet oud zijn, druk door automobielen worden gebruikt en nog geenszins gelijk op Java het geheele land doorkruisen, rijdt men langs onafzienbare reeksen van rijstvelden, thans onder water, die wel afgedamd zijn als op Java, doch in vee], veel grootere stukken; inderdaad beschikt de Annamiet gemiddeld over een veel grootere sawah dan de Javaan. 2) $\mathrm{Nu}$ en dan komt men groentetuinen voorbij en cok aanplant van suiker die alleen dient om door den inlander als versnapering gekauwd te worden; een poging, op groote schaal een veertigtal jaren geleden gedaan om een suikerfabriek met voordeel te doen werken, heeft jammerlijk schipbreuk geleden en is niet herhaald. Voorts ziet men overal klappers (kokospalmen), in pracht niet te vergelijken met de Nederlandsch-Indische, en ook kleine arekapalmen, waarvan de vrucht, de betelnoot, ook hier ijverig wordt gekauwd.

') "Uit Annam werd", schrịft de oud Gouverneur-Generaal de Lanessan in zijn voorbericht bij A. Gaisman's "'Oeuvre de la France an Tonkin," Parijs 1906, in die dagen "geklaagd over een zwijgende ontevreden"heid omdat het volk er verarmde door de voortdurend en te snel "verineerderde belastingen."

2) In Cochinchina beeft men ongeveer 2.4 inwoner per bebouwde hectare, dat is ongeveer $1 \frac{3}{4}$ inwoner per bahoe (Homan v. d. Heide, Ind. Genootsch. 1905 bl. 137). Op Java blijft, niet voor elken inwoner doch voor elken landbouwer, veelal slechts $t$ of $\frac{1}{2}$ bahoe over, hoogstens 2 bahoe. (Idem blz. 125).

Econ. 1911. 
Aldus bereikt men het vlek Biënhoa, aan de Donaï gelegen. Ofschoon in de onmiddellijke nabijheid van Saïgon, bezit het zijn eigen resident, doordat het de hoofdplaats is van de gelijknamige provincie, die tot de eerste kern heeft behoord van Frankrijk's bezit in het Verre Oosten. Dicht hierbij heeft de zooeven besproken suikerfabrick gestaan, die de Fransche regeering met alle mogelijke middelen heelt begunstigd, teneinde naast de aloude rijstcultuur een nieuwe te scheppen. De fabriek heeft echter slechts enkele jaren geleefd en schromelijke verliezen opgeleverd.

Dan voert onze weg door niets dan sawah's naar ThuDhau-Mot, een stadje van inlandsche, weinig verzorgde bamboe-woningen; alleen een marktloods en een beplant pleintje trachten er een Europeeschen tint aan te geven. De breede Saïgon-rivier stroomt hier dicht voorbij, en daar heeft men het droombeeld van de Seine nabij Parijs willen oproepen door er een eethuisje te bouwen, zooals men in die buurt zoo vele vindt. De eigenaar, een Annamiet, spijzigt er den reiziger als in Frankrijk. Het huisje draagt het zonderlinge uithangbord: Au goujon (een klein vischje) qui thet, de Annamitische spelling voor tete.

Een zeer eenvoudig ingericht treintje, dat bij het hiervoren genoemde Mytho begint en over smal spoor loopt, verbindt Saïgon en vervolgens het pas genoemde Bienhoa met de beste der drie Europeesche landbouw-ondernemingen van geheel Cochinchina. Het lijntje eindigt evein over de Annamitische grens. Ofschoon het slechts een paar honderd kilometer lang is, vormt het de eenige spoorwegverbinding in Cochinchina. Annam heeft voorts de half zoo lange ijzeren baan, die van de haven Tourane voert naar de hoofdstad Hué en iets verder. Tonkin is daarentegen rijk met spoorwegen begiftigd, die het verbinden met de noord-Annamitische stad Vinh en in twee armen met China. Cambodja en Laos hebben het ijzeren trekpaard nog niet gezien. Het ligt in de bedoeling den spoorweg van Cochinchina te doen aansluiten met dien, welke Hué aandoet, en hem dan tot Vinh door te trekken. Daardoor zouden Saïgon met Hanoï, Cochinchina over Annam met Tonkin en China verbonden zijn. Doch voor dit plan ontbreekt het aan geldmiddelen, nu het moederland terecht van meening 
is, voorloopig zijn reusachtige voorschotten te moeten staken; terecht, omdat de economische toestand der kolonie een nog grootere vastlegging van kapitaal thans niet wettigt.

De spoor van Cochinchina naar Annam is voor krijgsdoeleinden aangelegd. Inderdaad, de reiziger vraagt zich vergeefs af van welk vervoer $\mathrm{zij}$ moet bestaan. Reeds spoedig toch na Bienhoa is het uit met bebouwing, velden en revolking, en stoomen wij door louter oerbosch, onbenut, onbewoond, bestaande in hoofdzaak uit een mengeling van hemelhooge boomen, die zichzelven met reusachtige wortelribben stutten, en uit bamboe, dat hier leelijk, schots en scheef, in alle richtingen opgroeit. Bij de Annamitische grens welft de bodem zich bergachtig.

Aan het stationnetje Dau-Giai, uit bamboe opgetrokken en beheerd door een Annamiet, verlaten wij den trein en hereiken dan over een ellendigen landweg in een half uur de landbouwonderneming. Zij heet Susanneh. Een groot, scheef bamboe-huis op hooge palen herbergt den hoofdbeheerder; de eenvoudigste tabaksschuur in Deli biedt een heter onderkomen aan. De man, half Fransch half Anna. mitisch van bloed, werkte als klerk op een regeeringskantoor totdat hij hier geplaatst werd, heeft nooit eenig onderricht in den landbouw genoten en ontvangt ook geen enkel tijdschrift zooals zijn vakgenooten in NederlandschIndië om hem op de hoogte te helpen of te houden. Hij verving drie Fransche beheerders, die ook der zake volkomen onkundig waren en waarlijk maïs, het minst waardige produkt, op groote schaal waren gaan planten. Het hoofd der maatschappij is tevens spoorweg-directeur. Thans heeft men reeds $\$ 150.000$ verbruikt en daarmede slechts een kleine 200 hectaren 1) ontgonnen en beplant, ofschoon roor den grond, 2000 hect., als regeeringsconcessie niets hetaald werd. De loonen zijn betrekkelijk hoog, twee kwartjes en een liter rijst per dag; en toch valt het moeielijk volchende werkvolk te krijgen.

Twee jaar geleden is de tegenwoordige beheerder begonnen met hevea aan te planten. Die gedijt prachtig, ofschoon hier niet voldaan wordt aan den eisch van ge-

1) $7 / 10$ hectaren $=1$ bahoe. 
regelden regenval, daar deze slechts voldoende is tusschen April en November, en de overige maanden droog blijven. Ik zie boomen van een jaar oud, die reeds $31 / 2$ meter hoog zijn en de tweejarige kan ik nauwelijks met twee vingers omspannen. Ook de bladeren zijn kolossaal, bijna zoo groot als die van den ficus. Zal het echter mogelijk blijken in den regenloozen tijd te tappen? Tusschen de hevea in zie ik bergrijst geplant, tapioca die den grond uitmergelt en tabak, welke alleen roor inlandsch gebruik bestemd is en zeer zorgeloos wordt bereid; zij brengt $\$ 1.20$ per kilo op. Voorts wat sesamzaad, een driemaandscultuur; uit de vruchtzaadjes dezer ongeveer een meter hooge plant wordt eetbare olie geslagen. Eindelijk heel kleine stukjes grond met maïs en suiker; katoen heeft men opgegeven. Ziedaar de beste onderneming van geheel Cochinchina; zij maakt een poveren indruk.

Behalve door den prachtigen stand der hevea wekt zij echter in nog een opzicht belang. De maatschappij plant namelijk de inlandsche moerbei aan en heeft bamboe-woningen en -werkplaatsen ter beschikking gesteld van een liefdadige vereeniging, die er met behulp en ten bate van inlandsche weezen en verlaten kleine kleurlingen de zijdecultuur tracht uit te oefenen. De opbrengst wordt tusschen de maatschappij en de vereeniging gelijkelijk verdeeld. De vereeniging beoogt, haar pleegkinderen in staat te stellen zelven hun kost te verdienen, totdat de meisjes trouwen en de jongens volwassen zijn. Aan het hoofd staat hier een Fransche zuster, de eenige blanke der geheele streek, wier zonnig, vredig wezen en toewijding weder een diepen indruk maken. Ik zeg weder, omdat de reiziger die telkens terugvindt in allerlei uithoeken der wereld bij roomsche liefdezusters. Het is mij, als stond ik weer voor de Fran. sche verpleegster in het verre Panama, die, ofschoon spierwit van de malaria, blijmoedig den hospitaaldienst waarnam; of in het koortsland bij uitnemendheid, de oudHollandsche Goudkust, waar een heele stoet Fransche zusters, gedeeltelijk behoorende tot den hoogen adel, zich met den dood dagelijks voor oogen glimlachend wijdde aan de opvoeding van kleine zwarten. De zuster hier draagt de witte huif en donker blauwe kleeren zooals in Frankrijk, 
en evenzoo het viertal Annamitische zusters die haar ter zijde staan. De laatsten kennen alleen de inlandșche taal, die de bestuurster, ofschoon eerst een jaar hier, vlot spreekt. Allen huizen in kleine, inlandsche woningen op palen. De Annamitische zusters kennen de zijdeteelt van huis uit, want $z i j$ is inheemsch in geheel Indo-China, evenals in Siam; doch al die landen brengen tegenwoordig slechts zeer weinig zijde voort. De Siameesche regeering heelt claarom Japansche deskundigen aangesteld als wandelleeraars en bestuurders van modelhoeven en koestert van dien maatregel groote verwachtingen. Frankrijk heeft zich in deze richting nog onbetuigd gelaten.

Men houdt de moerbeiplanten laag, omdat anders de bladeren te hard worden. De laatste stapelt men in bundels up en die snijdt men fijn, omdat de zijdeworm de ongesneden bladeren alleen kan eten als hij volwassen is. Dit snijdsel verspreidt men over ronde bamboe-bakken van een meter middellijn en bestrooit het met de pas uitgekomen wormpjes. De bakken bergt men dan in schuren, die op palen moeten staan; anders sterven hier de wormen. Daar eten deze gedurende eenige dagen onafgebroken voort en slapen dan een vol etmaal, gedurende hetwelk men zich, ils waten het menschen, moet onthouden van aanraking en gerucht. Is de bak bijna leeggegeten, dan rolt men de diertjes zacht in de bladeren en plaatst hen op versch gerulde bakken over. Door hun verbazend eetvermogen groeien zij sterk en de hier in hoofdzaak geteelde soort krijgt de lengte van een vingerlid en den omvang van een dun potlood. Andere soorten worden zelfs een vinger dik. De volwassenen plaatst men vervolgens op takkebossen en laar maken zij huin cocons, d. w. z. zij omringen zich met zijdedraad, in 24 uur. De cocon laat men drie dagen liggen en gaat dan den draad afrollen, spinnen. Daartoe werpt men de cocons in kokend water, waardoor de worm sterft en wikkelt den draad, die vaak een lengte van 200 meter hereikt, af. De buitenste draden zijn eenigszins hard en worden ter vervaardiging der ruwe zijde afzonderlijk verkocht. Van de binnenste voegt men er zeven samen en wikkelt hen dan door een glazen oog over een draaiend wiel op een spoel tot een gesponnen draad samen. De na- 
tuurlijke kleur is helder geel. Eenige cocons verspint men niet. Daaruit komt na vijf dagen de vlinder te voorschijn, die te kleine vleugels heeft om weg te vliegen en zich dadelijk paart. Reeds twee uur later komen de eieren te voorschijn, de vlinder sterft na een etmaal en in tien dagen brengt het ei den kleinen worm te voorschijn. Het geheele verloop duurt 25 tot 30 dagen.

Behalve deze werkzaamheid leeren de kinderen lezen en schrijven in het Annamitisch en voorts den roomschen godsdienst, het laatste van een inlandschen vader. Naar 's lands wijs en zwart gekleed, laat hij ons in zijn ruime woning, die evenals zijn kerkje geheel uit bamboe is gevlochten, uitrusten ran den in dit klimaat vermoeienden ('mmegang en verkwikt ons met Spaanschen miswijn. Fransch lient hij niet en nooit verliet hij Cochinchina; toch houdt hij den dienst in het Latijn.

Dan tijgen wij ten maaltijd bij den beheerder der onderneming, die zich rergast aan wat wij, op raad van anderen, aan voedsel hebben meegebracht; zijn bestuur verwent den man niet en hij moet leven van rijst, eieren en wijn.

Dezelfde spoorlijn voert $\mathrm{mij}$ in omgekeerde richting; over Saïgon naar Mytho, op weg naar Cambodja. Wel verbindt een kanaal deze plaats met Saïgon; maar daarover wordt alleen de rijst vervoerd, ondat de trein, ofschoon niet meer dan 25 kilometer per uur afleggend, Mytho in twee uren van Saïgon bereikt. Men spoort weder door niets dan sawah's, op welke zich tal van $z$ warte buffels $\log$ voortbewegen; zij lijken mij grooter clan die op Java. Mytho had in de eerste jaren der Franschen veel belang roor hen en huisvestte toen een groot aantal blanken. Thans is het ingekrompen tot enkele Europeesche huizen en een groep inlandsche hutten. De laatste blijken telkens achter te staan bij die der Javanen, zijn slordig en trots de vochtigheid van den bodem gewoonlijk niet op palen gebouwd; nooit missen zij een indeeling in vertrekken.

Hier bestijgen wij het stoomschip Battambang, dat vannacht van Saïgon over zee hierheen gekomen is. Eigendom der reeds besproken Messageries Fluviales, die door de 
zware toelage der koloniale schatkist feitelijk een monopulie heeft op de Mekong, overtreft het alle stoombooten op welke ik ooit gevaren heb in achterlijkheid en verwaarloozing. Op het heele schip is geen enkele lamp te bekennen, zelfs niet voor olie. Mijn klamboe (gazen bedgordijn) is grijs van het vuil, gescheurd en vol spinrag. Toch is dit stoomschip, naar men mij verzekert, het beste der lijn. Mijn eenige reisgenoot is een kleurling uit Manilla, die te Pnom Penh, de hoofdstad van Cambodja, vee gaat halen, dat zijn land in onvoldoende hoeveelheid oplevert. De tweede klasse betrekken deftige Annamieten, die over een wit pak als het onze een overkleed dragen van doorschijnende zwarte zijde en om de slapen een opgerolden witten doek hebben herestigd. Onder de dekpassagiers bevinden zich cen aantal Maleiers uit het schiereiland Malakka en een Kling. 1)

De rivier vertoont door haar bruine kleur en machtige breedte, die zelfs tot in Siam aanhoudt, haar karakter van alluvialen stroom. Inderdaad is het ontstaan van geheel Cochinchina te danken aan de Mekong, aan het slib dat zij op haar langen weg uit het gebied der eeuwige sneeuw heeft medegevoerd en hier heeft laten vallen. ") Talrijke schilderachtige kreken monden erin uit. De oevers zijn parkachtig met boomen beplant. $\mathrm{Nu}$ en dan leggen wij aan bij een dorp. De woningen heeft men er louter uit atap ${ }^{3}$ ) gebouwd en eerst aan den middenloop der rivier, waar de grond al te drassig is, op palen geplaatst. Zij liggen onder armelijke klapperboomen en areka-palmen en zijn omgeven door pisang-struiken en sawah's. Hier buiten zie ik alle mannen met het bovenlijf naakt, en in groote hoereelheden wordt onze Javaansche sarong gedragen, kenbaar aan de tric-trac punten der kapalla's (hoofden). Vele groote, stevige rijstschepen zakken de rivier af. $\mathrm{Zij}$ hebben stroo-woninkjes achterop en zien er uit als Hollandsche tjalken, behalve dat zij geheel ongeverfd zjjn. Meestal

1) Daaronder verstaat men in de Straits-Settlements koelies uit zuidelijk Voor-Indië.

2) J. Homan van der Heide, Indisch Genootschap 1905 blz. 119.

$\left.{ }^{3}\right)$ Naast elkander geregen smalle, lange, harde bladeren van den nipapalm of wel groote harde grasscheuten (alang-alang) van denzelfden vorm, 
Ireden vrouwen als schuitenvoerders op; bij de Annamieten valt het grove werk voornamelijk haar ten deel.

Het regent thans, September, elken dag, maar slechts gedurende een paar uren. Het natte seizoen in Cochinchina begint in Mei, openbaart zich het sterkst in de volgende maand, soms in September, ${ }^{1}$ ) en neemt daarna geleidelijk af, om in November of December voor het droge jaargetijde plaats te maken. Dan, vooral in Februari en Maart, is een warmte van over de honderd graden F. geen uitzondering. In Cambodja houden de regens soms iets vroeger op. Voor zoover het land niet bergachtig is, loopen de warmtegraden der verschillende gedeelten van Indo-China op hetzelfde tijdstip niet veel uiteen; de regenval wel, zooals hiervoren opgemerkt.

1) Zie de graphische voorstelling Builetin Economique, Hanoï Nov. Dec. 1908.

Hendrik P. N. Muller. 